\title{
Anatomical and Adaptation Features of Pistacia atlantica Desf. to Adverse Climate Conditions in Algeria
}

\author{
Mohamed Amara',2, Mohammed Bouazza ${ }^{3}$, Mohannad G. Al-Saghir ${ }^{*}$ \\ ${ }^{1}$ Bouchaïb Belhadj University Centre, Department of Natural Sciences and Life, Aïn Temouchent, Algeria \\ ${ }^{2}$ Laboratory of Ecology and Management of Natural Ecosystems, Abou Bakr Belkaïd University, Tlemcen, Algeria \\ ${ }^{3}$ Laboratory of Ecology and Management of Natural Ecosystems, Department of Ecology and Environment, Abou Bakr Belkaïd \\ University, Tlemcen, Algeria \\ ${ }^{4}$ Department of Environmental and Plant Biology, Ohio University, Zanesville, Ohio, USA \\ Email: *al-saghi@ohio.edu
}

How to cite this paper: Amara, M., Bouazza, M. and Al-Saghir, M.G. (2017) Anatomical and Adaptation Features of Pistacia atlantica Desf. to Adverse Climate Conditions in Algeria. American Journal of Plant Sciences, 8, 137-153.

http://dx.doi.org/10.4236/ajps.2017.82011

Received: December 12, 2016

Accepted: January 17, 2017

Published: January 20, 2017

Copyright (C) 2017 by authors and Scientific Research Publishing Inc. This work is licensed under the Creative Commons Attribution International License (CC BY 4.0).

http://creativecommons.org/licenses/by/4.0/

\begin{abstract}
This work was conducted to assess the anatomical features of Pistacia atlantica Desf. under Mediterranean semi-arid climate conditions. In this study, phytoecological approach was used at different observation scales including the large ecological scale. 11 samples of $P$. atlantica species were randomly selected in order to study the anatomy of leaves and branches. The results show that leaves have palisade parenchyma occupying almost the entire mesophyll, measuring 100 to $170 \mu \mathrm{m}$. While in branches, the only pith occupies $38 \%$ followed by the xylem (24\%), relative to the rest of the tissue (epidermis, periderm, collenchyma, pericyclic fiber, secretory duct and phloem). The current results suggest that $P$. atlantica species has xeromorphic anatomical characters, giving it great ecological plasticity in an arid environment. Moreover, this study shows that the human activities are causing local extinction of this rare species in Algeria.
\end{abstract}

\section{Keywords}

Pistacia atlantica, Xeromorphic, Anatomy, Adaptation, Arid/Semi-Arid, Algeria

\section{Introduction}

Pistacia atlantica Desf. is a tree species of the genus Pistacia L. which is in danger of extinction in Algeria. The species is located in the Algerian north westernmost. The species occupies presently a meager proportion of the territory that it once covered [1]. 
The species is economically important in Algeria. It is important to combat soil erosion; it strengthens the soil and is used for reforestation of arid and steep slopes and against landslides. The seeds are edible oil seeds and contain up to $60 \%$ fat $[1]$.

Many taxonomic studies have described the species [2]-[9]. Few studies have been published on the anatomy of the Pistacia genus and even less on the $P$. atlantica [10] [11] [12] [13] [14]. It is urgent to deal with this plant genetic erosion phenomenon based on a large-scale research on this species autecology.

Additionally, the study of the internal anatomy of the plant leaves and branches along their modifications and adaptations remains essential for a better autecological diagnostic of the plant species. Unfortunately in Algeria and specifically in the north westernmost of the country, no work has been published on the anatomical and histometrical characters of this rare species. Therefore, this study objective was to assess the anatomical features of $P$. atlantica under Mediterranean semi-arid climate.

This study is the first to study the internal structures of leaves and branches of $P$. atlantica in this region.

\section{Materials and Methods}

\subsection{The Study Area}

The study area is located at the north westernmost Algeria (Figure 1). It is part of the western area of Pistacia. atlantica in the Oran area. The coastal mountain range of Traras and mounts of Tlemcen respectively constitute the northern and southern boundaries of the study area. It is bounded on the west by the Moroccan border and to the east by the Isser Wadi valley.
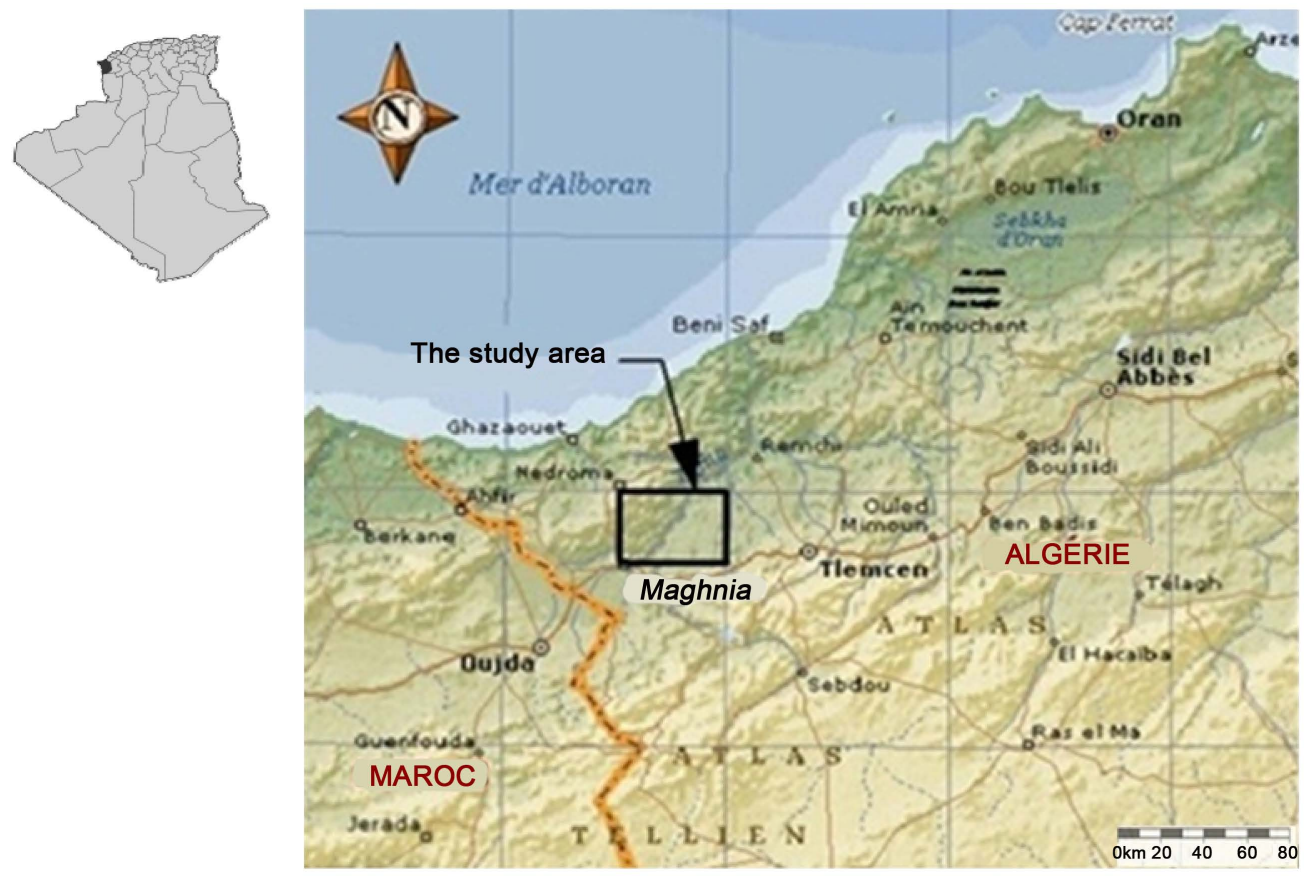

Figure 1. The study area. 


\subsection{Bio Climate}

The area is characterized by a semi-continental Mediterranean climate. The arid enclave surrounding Maghnia is thus characterized by a thermal continental micro-climate, cold in winter and very hot in summer [15].

The Emberger's pluviothermic climagramm (Figure 2) ranks the area between the mean arid level with temperate winter $\left(\mathrm{Q}_{2}=26.89\right.$ and $\left.\mathrm{m}=3.21^{\circ} \mathrm{C}\right)$ and the lower semi-arid level with temperate winter $\left(\mathrm{Q}_{2}=41.16\right.$ and $\left.\mathrm{m}=5.5^{\circ} \mathrm{C}\right)$.

The Bagnouls and Gaussen (1957) [16] ombrothermic diagrams for Zenata and Maghnia weather stations during the 1980-2007 period (Figure 3) illustrate the extent of the dry period that reaches 07 months (April to October) [9]. The length of the dry season is generally correlative of its intensity; but there are important differences depending on whether the annual dry season is continuous or not; that is to say, whether the annual rainfall regime is unimodal, bimodal and/or multimodal [17] [18].

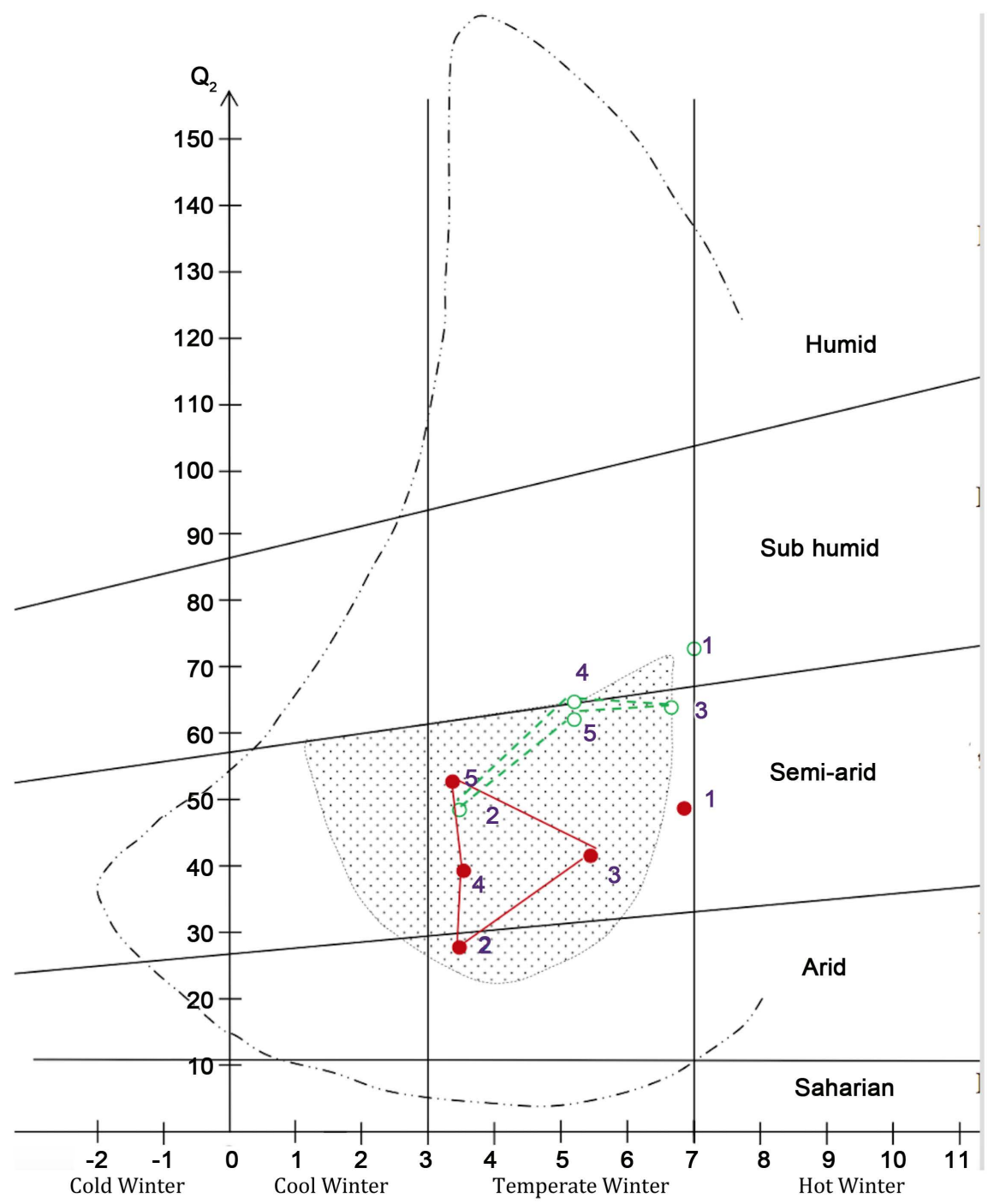

Figure 2. Emberger's Emberger Pluviothermic quotient $\left(\mathrm{Q}_{2}\right)$ for the study area [9]. 2 = Maghnia; 3 = Zenata. 

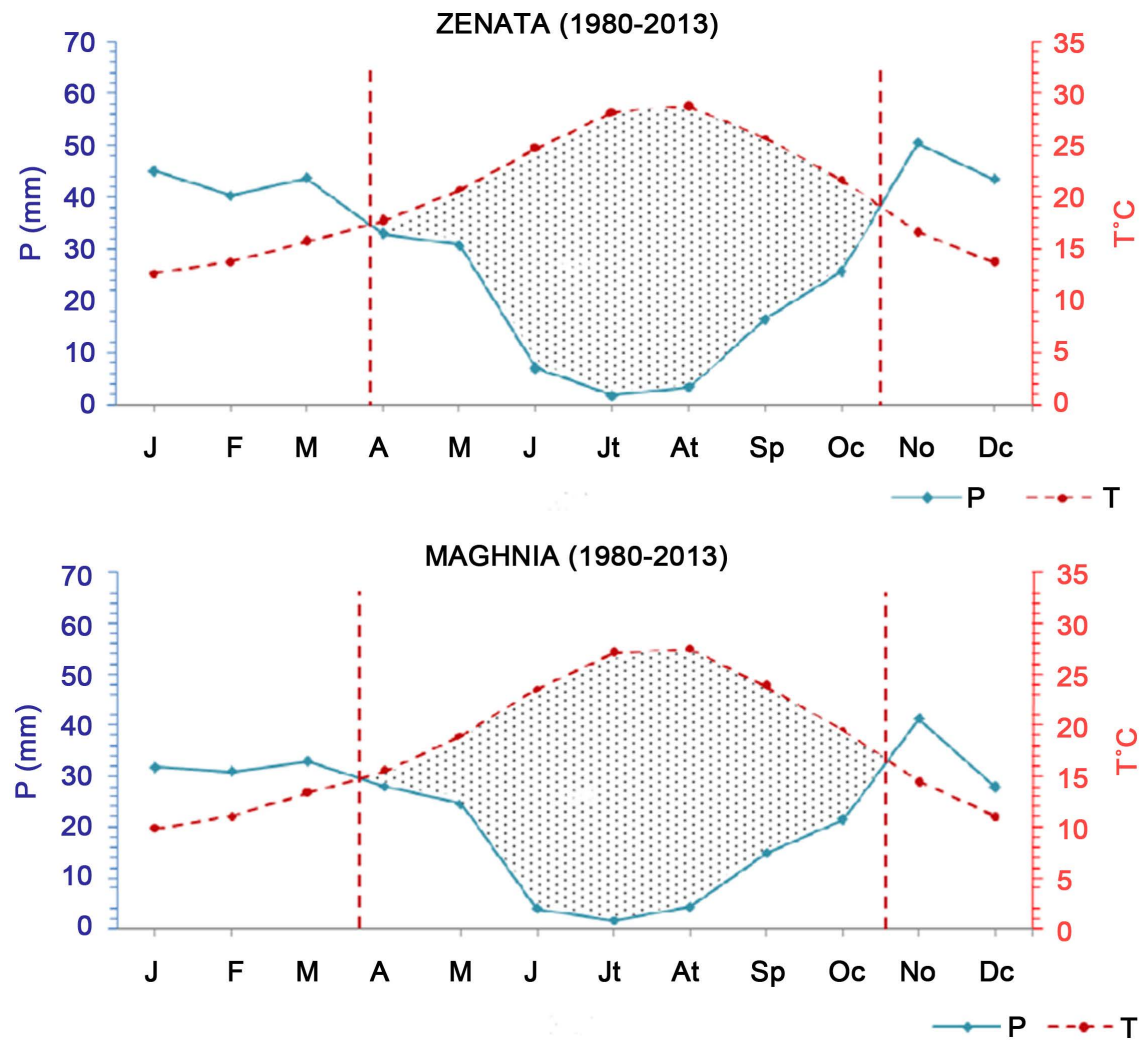

Figure 3. Ombrothermic diagrams for the study area (1980 to 2013). $=$ = Period of drought.

The annual rainfall varies between 249 and $327 \mathrm{~mm}$. The monthly rainfall patterns are characterized by two maxima rainfall, one in November and one in March. The spring and winter maxima allow several plant species, such as Stipa tenacissima [19]; Holm oak (Quercus ilex), the Aleppo pine (Pinus halepensis), to start the summer season with relatively large water reserves [20].

As for the average annual temperatures, they oscillate between $17.67^{\circ} \mathrm{C}$ and $20.42^{\circ} \mathrm{C}$. The extreme values are strong limiting factors whose effectiveness depends on certain levels and their frequency of occurrence [15]. In our region, the mean thermal maxima of the hottest month $\left(\mathrm{M}^{\circ} \mathrm{C}\right)$ range from $32.7^{\circ} \mathrm{C}$ (Zenata) and $35.01^{\circ} \mathrm{C}$ (Maghnia) and that contributes to the enhancement of evapotranspiration and therefore aridity of the environment.

\section{Sample Collections and Anatomical Cross Sections}

The sample collection was carried out in the Maghnia Tell plain (North westernmost Algeria) characterized by a semi-arid climate. Anatomical sections were performed for the leaves and branches of 11 random samples of Pistacia atlantica. Sample collection was performed at the base of the tree crown. The authors taxonomically identified the plant samples.

Cross sections were done "freehand" and to differentiate between the xylem and phloem we used the double staining with methyl green-red Congo [21]. A Light compound microscope with a stage micrometer was used to observe the 
sections and measure the different tissues. Pictures were taken at magnifications $10 \times, 16 \times$ and $40 \times$.

\section{Results}

All leaves and branches tissues were measured as shown in Table 1 and Table 2. The anatomical sections of Pistacia atlantica leaves and branches were studied (Figures 4-8).

\subsection{Branches}

The results show the following tissues of the branches:
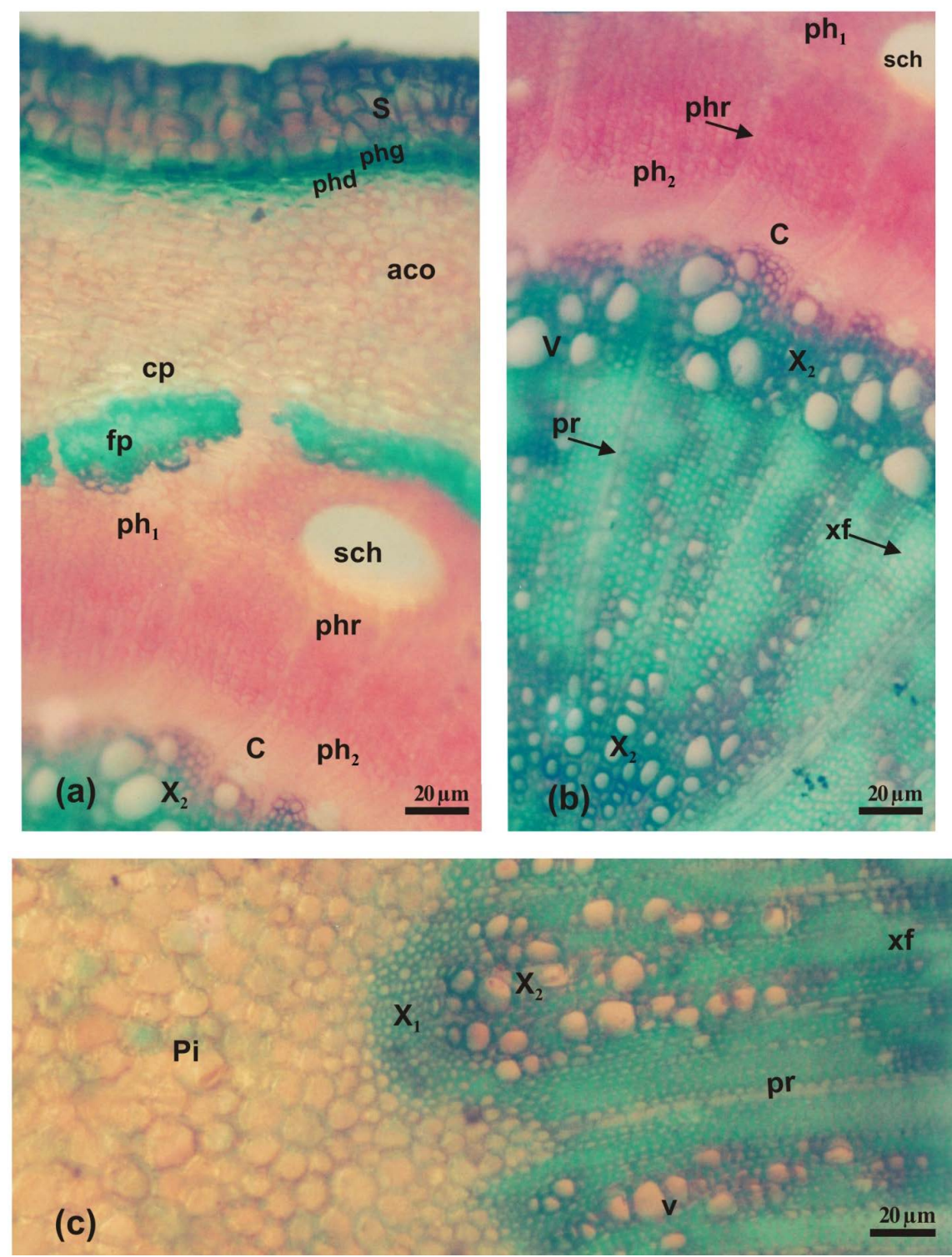

Figure 4. Histological sections of the branches of Pistacia atlantica (at 10× magnification). (a) Main tissues of branch include angular collenchyma (ac), pholem rays (phr), secondary phloem $\left(\mathrm{ph}_{2}\right)$ and secretory channel ( $\mathrm{sch}$ ); (b) Main tissues of branch include phloem rays (phr), pith rays (pr) and xylem fiber (xf); (c) Main tissues of branch include primary xylem $\left(\mathrm{X}_{1}\right)$, secondary xylem $\left(\mathrm{X}_{2}\right)$ and pith $(\mathrm{pi})$. 

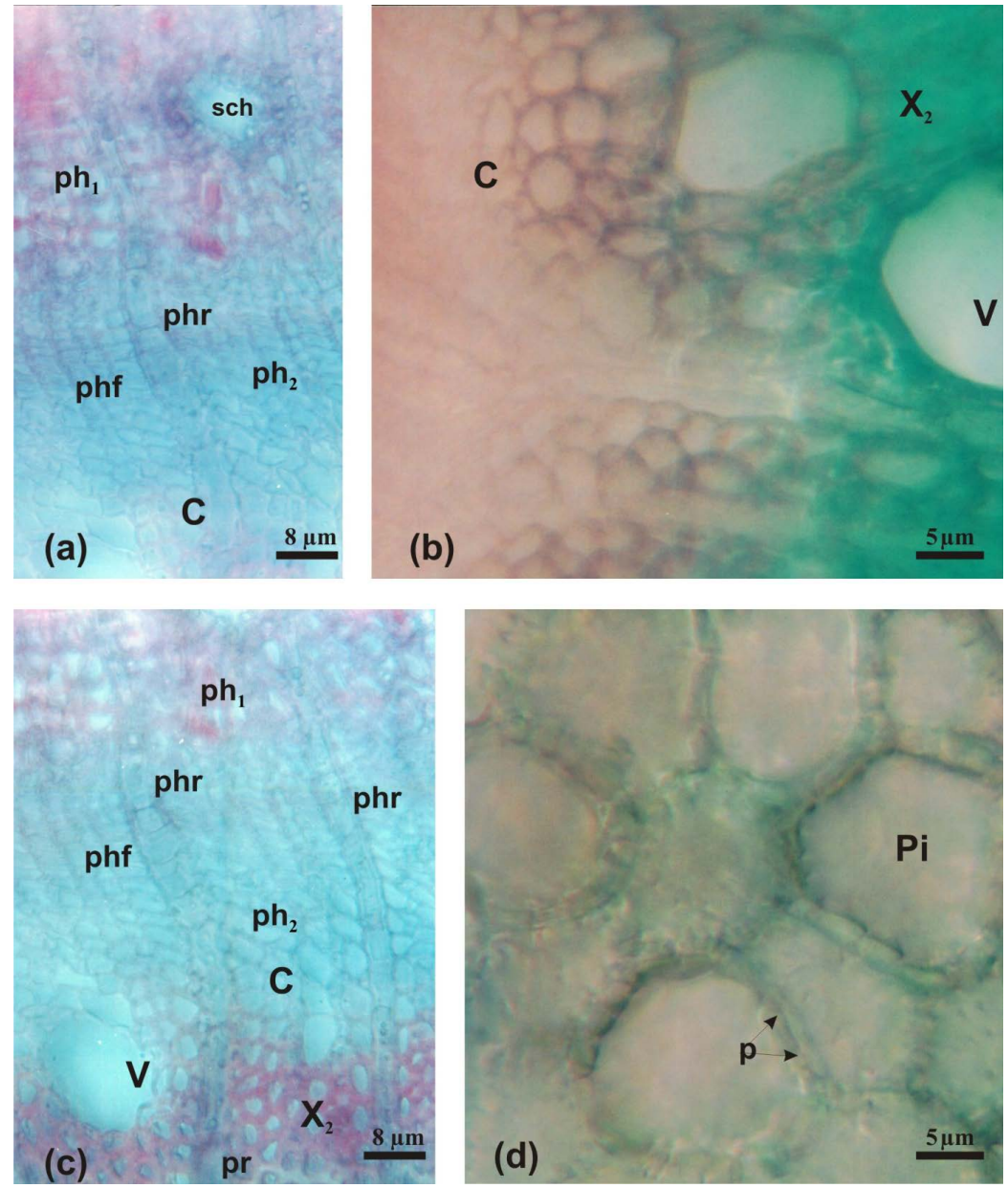

Figure 5. Histological sections of $P$. atlantica branch (at $16 \times$ magnification). (a) Main tissues of branch include cambium (c), pholem rays (phr), secondary phloem $\left(\mathrm{ph}_{2}\right)$ and secretory channel (sch); (b) Main tissues of branch include cambium (c) and secondary xylem ( $\left.\mathrm{x}_{2}\right)$; (c) Main tissues of branch include cambium (c) and secondary xylem ( $\left.\mathrm{x}_{2}\right)$ and vessel (v); (d) Main tissues of branch include punctuation (p) and pith (pi).

Table 1. Results for branches histometry $(\mu \mathrm{m})$.

\begin{tabular}{cccccccccc}
\hline Tissues & \multirow{2}{*}{ Epidermis } & Periderm & Co & pf & sch & Phloem & Xylem & Pith & Total \\
\cline { 1 - 3 } Samples & 10 & 68 & 200 & 38 & 53 & 236 & 392 & 614 & 1611 \\
$\%$ & 1 & 4 & 12 & 2 & 3 & 15 & 24 & 38 & 100
\end{tabular}

Abbreviation: $\mathrm{sch}=$ secretory channel; $c 0$ = collenchyma, $\mathrm{pf}=$ pericyclic fiber.

Table 2. Results for leaves histometry $(\mu \mathrm{m})$.

\begin{tabular}{ccccccccccc}
\hline Tissues & \multicolumn{4}{c}{ Mesophyll } & \multicolumn{1}{c}{ Main Nervure } \\
\hline Samples & uep & pp & lep & Total & uep & uco & cvb & lco & uep & Total \\
\hline Mean & 17 & 140 & 16 & 173 & 12 & 112 & 177 & 81 & 12 & 394 \\
$\%$ & 10 & 81 & 9 & 100 & 3 & 28 & 45 & 21 & 3 & 100 \\
\hline
\end{tabular}

Abbreviation: lco = lower collenchyma; uco = upper collenchyma, lep =lower epidermis, uep = upper epidermis; $\mathrm{cvb}=$ cribro-vascular bundle, $\mathrm{pp}=$ palisadic parenchyma. 

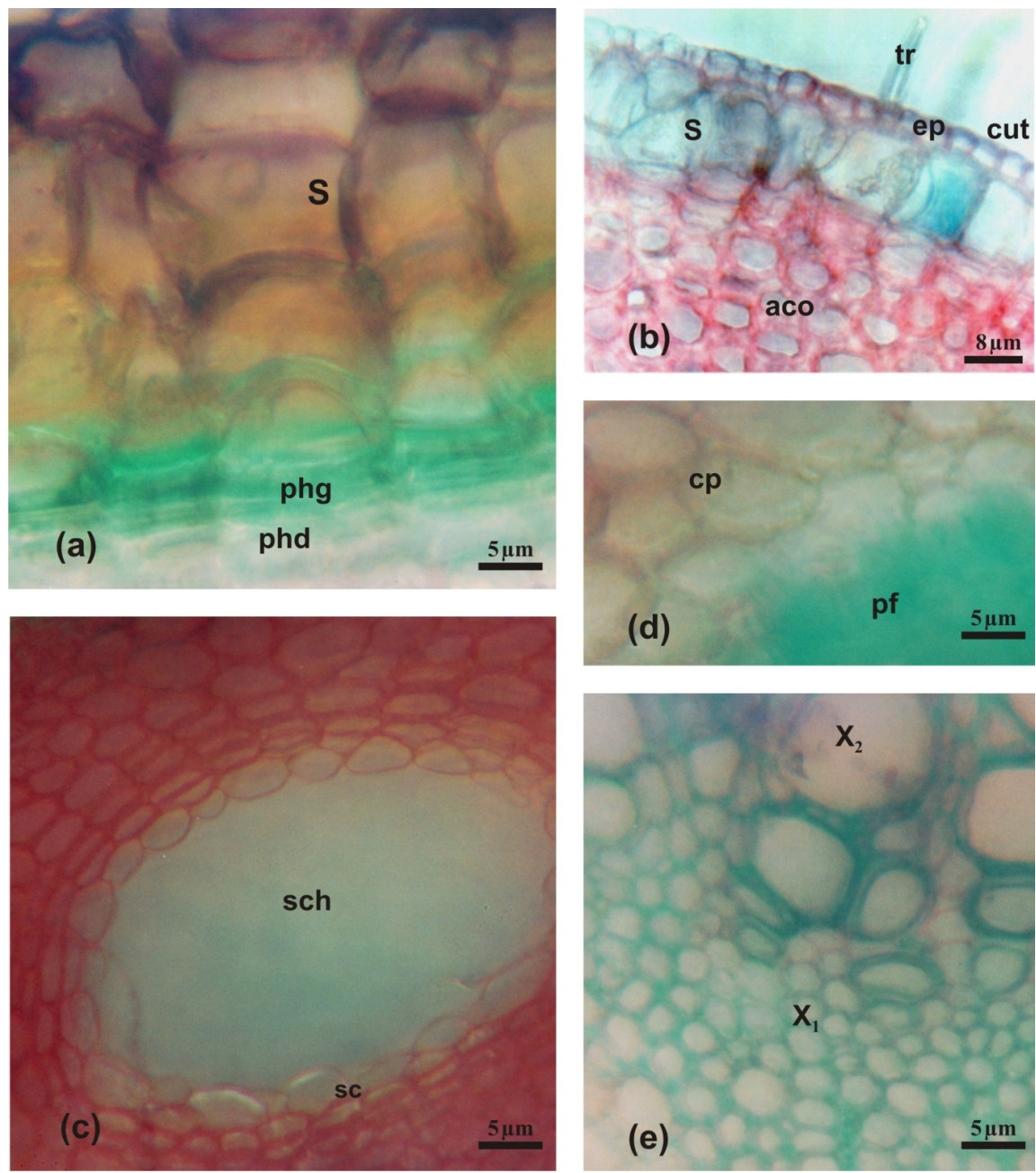

Figure 6. Histological sections of P.atlantica branch (at $40 \times$ magnification). (a) Main tissues of branch include suber (s), phelloderm (phd) and phellogen (phg); (b) Main tissues of branch include trichomes (tr), cutin (cut) and epidermis (ep); (c) secretory channel (sch); (d) Main tissues of branch include primary xylem $\left(\mathrm{X}_{1}\right)$ and secondary xylem $\left(\mathrm{X}_{2}\right)$.

\section{The Epidermis}

This superficial layer is constituted by a single layer of cells with a thickness up to 10 microns. (Figure 6(a)). Some epidermal cells differentiate into unicellular hairs (trichomes).

\section{The Periderm}

The periderm consists of phellem, phellogen and phelloderm whose suber remains the most significant tissue; measuring up to $30 \mu \mathrm{m}$ to $100 \mu \mathrm{m}$ with an average of 68 microns (Figure 4(a) and Figure 6(a)).

1) The phellem (suber or cork): The cork cells have regular shapes and are ocher yellow or yellow brown to brown. When young, the suber can keep its natural transparent color (Figure 6(b)).

2) Phellogen: is the subero-phellodermal generator sitting, it is a layer of short lines of initial tabular cells.

3) Phelloderm: is a thin layer of differentiated tabular cells under the phellogen. The phelloderm lignification was observed. 

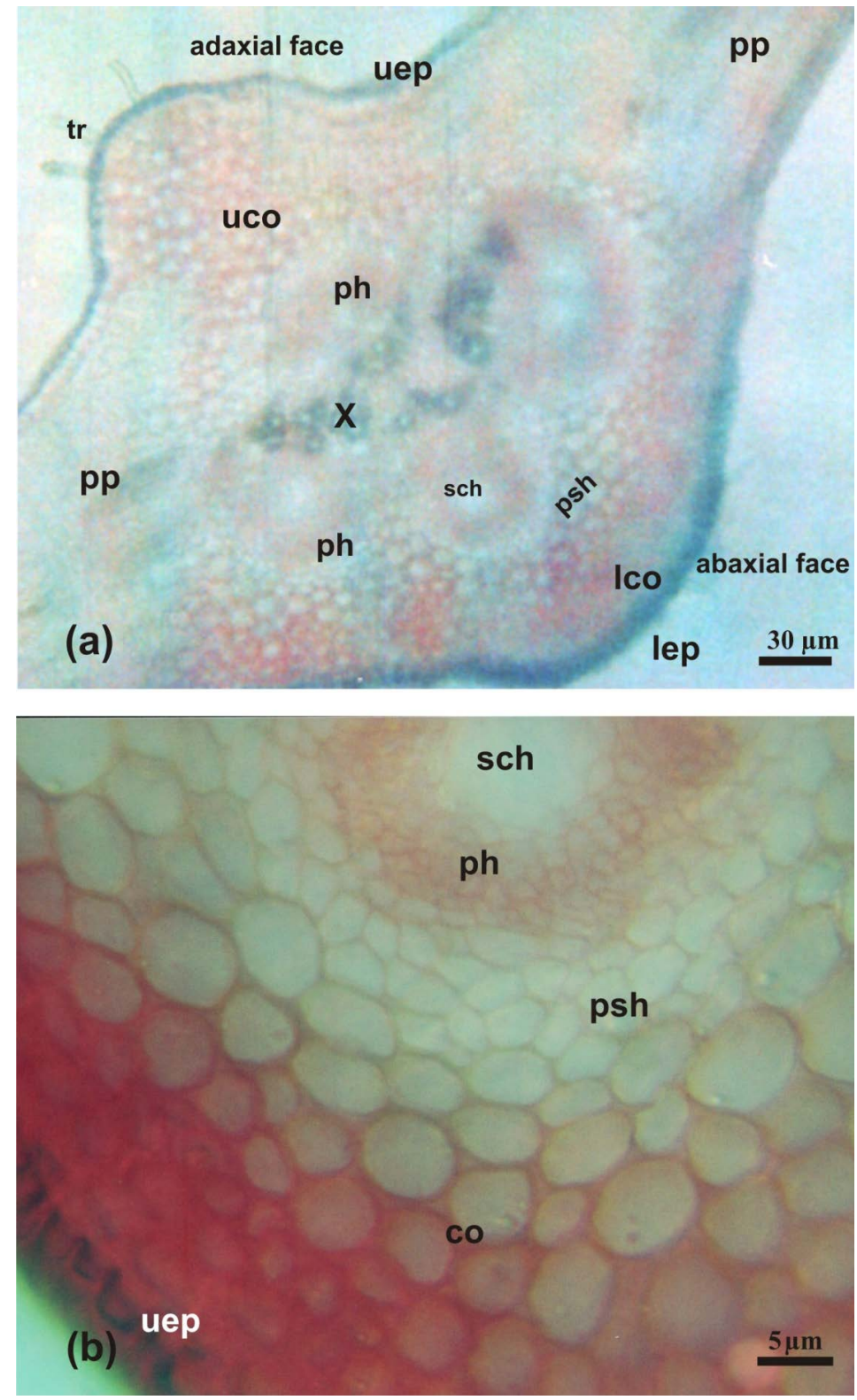

(b)

Figure 7. (a) \& (b) The conducting bundles of $P$. atlantica leaf (at $10 \times$ magnification).

\section{The collenchyma}

There is a set of pink or red cells, more or less elongated, spindle-shaped with a cellulosic thickening located at the corners (Figure 4(a) and Figure 6(b)). The thickness of this angular collenchyma oscillates between 90 and 440 microns with 200 microns on average (Table 1).

\section{The cortical parenchyma}

It is absent when the subject is young (Figure 6(b)). For grown subjects, we have a more or less pronounced appearance of thin wall parenchymal cells; this tissue stays in contact with the pericyclic fibers (Figure 6(d)).

\section{The pericyclic fibers}

Highly elongated cells with kidney-shaped wall with a large lignified second- 

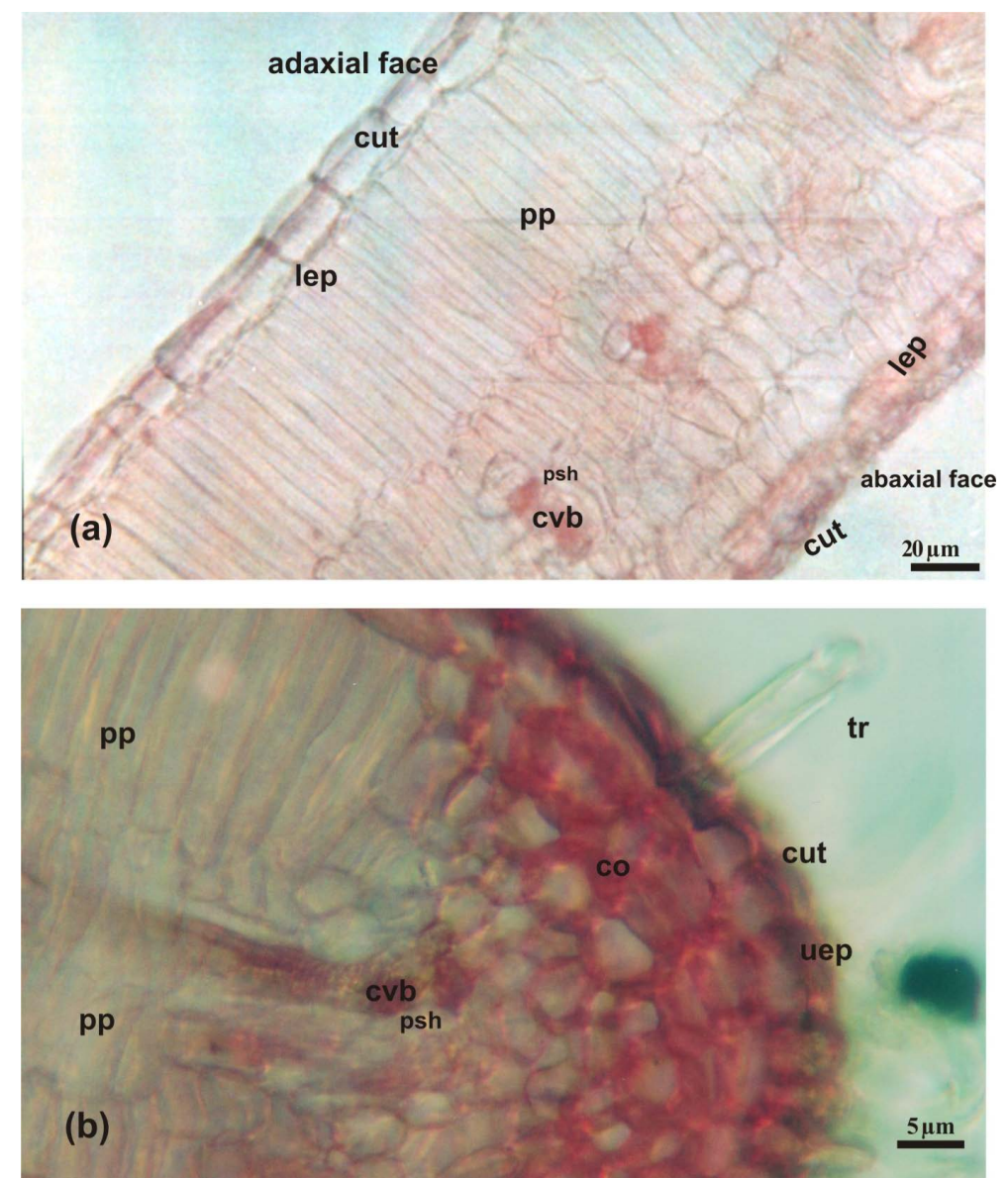

Figure 8. (a) \& (b) Mesophyll section of $P$. atlantica leaf (at $40 \times$ magnification).

ary thickening; reach up to 38 microns on average (Figure 4(a) and Figure 6(d)) with a margin of 30 to 50 microns (Table 1).

\section{Secretory or excretory channels}

These circular cavities are limited by one or two layers of small secretory cells regularly arranged (Figure 4 and Figure 6(c)). Their diameters can reach 90 microns (Table 1). Smaller secretory ducts are located more deeply in the phloem (Figure 5(a)).

\section{Phloem}

This part consists of a set of parenchyma cells with rather thick walls of a cellulosic nature; phloem fibers and rays. This tissue complex thickness is of 236 microns on average; with an interval between 170 and $400 \mu \mathrm{m}$ (Table 1).

\section{Cambium}

This is a phloem-woody base generator located between the xylem and phloem, its color is lighter than the phloem (Figure 4 and Figure 5).

\section{Xylem}

This tissue is made up of various cellular elements: the vessels, the wood fibers and wood parenchyma cells (or medullary rays) (Figure 4, Figure 5(b), Figure $5(c)$, Figure 6(e)). We recorded diameter measurements from 200 to $870 \mathrm{mi}-$ crons (Table 1). 


\section{Pith}

This parenchymal tissue fills the center of branches (stems) (Figure 4(c) and Figure $5(d))$ characterized by a very large diameter growth (614 $\mu \mathrm{m}$ on average).

\subsection{Leaves}

Cross sections of the different leaves revealed that the leaf blade is made of the following tissues: The epidermis; the assimilation tissue (mesophyll); and the conducting bundles (veins and vascular system).

\section{The epidermis}

This is the thinner layer of the unicellular cells with a thickness which does not exceed 20 microns. From this epidermis, unicellular hairs called trichomes develop (Figure 7(a) and Figure 8(b)).

\section{The assimilation tissue (mesophyll)}

It is, at the leaf blade, the middle part of the leaf, between the epidermises. It is composed of elongated cells, arranged perpendicularly (Figure 8). The palisade parenchyma is highly developed, multilayered; located on both sides of the leaf. It occupies almost the entire mesophyll measuring 100 to 170 microns with an average of 140 microns (Table 2).

\section{The conducting bundles (nervures)}

The main nervure is highly prominent on both sides of the leaf. It is formed by 4 opposed cribro-vascular bundles three of which are arranged in a phloemwoody arc facing the ventral side of the leaf blade. In each bundle, the xylem is oriented towards the center and the phloem outwards. Secretory ducts, with a diameter of $30 \mu \mathrm{m}$, on the average, are observed in the phloem (of bundles). On the bilateral plane of symmetry, the thickness of all the conducting bundles and secretory channels varies between 90 and $280 \mu \mathrm{m}$ (Table 2).

Around the conducting bundles, there is a continuous ring of parenchyma or perivascular sheath (Figure 7(a) and Figure 7(b)). The collenchyma is characterized by its remarkable development on both sides of the main nervure reducing to 120 microns for the lower collenchyma and $180 \mu \mathrm{m}$ for the upper collenchyma. Fine nervures are located within the mesophyll; each of them is formed by a reduced cribro-vascular bundle and surrounded by a layer of cells (Figure 8(a) and Figure 8(b)).

\section{Discussion}

This study was conducted on the anatomy of Pistacia atlantica leaves and branches and it is the first study to report the anatomical features of $P$. atlantica under Mediterranean semi-arid climate in Algerian north westernmost.

This study reveals that the internal structure of this species does not escape from all the major anatomical features of most dicotyledonous; but there are some differences that reflect well on this species adaptation to such arid environment.

The study of cross sections of $P$. atlantica branches reveals a diverse set of tissues of primary and secondary structure by meristematic origin. These coatings 
cells are usually monolayered and nested within the other like the stones of a puzzle, without intercellular spaces (Figure 6(b)). Moreover, once the primary growth is completed, it is followed by a very different growth. It is due to the functioning of the secondary meristems or generating zones which are divided regularly in an arched manner or tangentially. Indeed in older branches, the epidermis is replaced by another protective tissue, secondary in nature, deriving from phellogen.

Periderm includes: an outer layer of dead cells, the phellem or cork; a generator cell layer, the phellogen producing outward cork cells; and finally an inner layer, the phelloderm, thin, containing living cells produced in the phellogen inner face [22]. The phelloderm is a living tissue in parenchymal nature [23], but always with thin pecto-cellulose walls [24]. Cork is however made up of small dead cells with suberized impermeable walls; acting as thermal insulation and protection [25]. It is also constituted by a regular assembly of many layers of rectangular cells and closely juxtaposed which the wall, thick and dark, is fully suberized. The current results indicate the presence of four layers of cells without intercellular space. The periderm can reach a thickness of 100 microns, about $4 \%$ on average (Table 1). In fact, bark and cork protect effectively from water loss, infection by micro-organisms and intense light and heat effect [23].

In some vascular plants, including the Chamaephytes and most Phanerophytes like that of Pistacia atlantica Desf., the diameter increment is provided, in addition to periderm by another lateral meristem, deeper, secondary in nature, called the cambium or the phloem-woody generator sitting. Lateral meristems add volume to plants by producing secondary conductors tissues and periderm [26].

The phloem-woody cambium produces secondary conducting tissues that add directly to the primary elements: the phloem or secondary phloem to the outside and wood or secondary xylem inward. The production of cells on each side of the cambium is not regular [25]. In general, a high activity corresponds to the timber port with $392 \mu \mathrm{m} \mathrm{24 \%}$ against 236 microns (15\%) for the phloem (Table 1). Each spring and summer, as the primary growth lengthens shoots, the secondary growth thickens the portions of the branch that formed in previous years [26].

The thickening of the conducting secondary tissue inevitably leads to the narrowing of xylem and primary phloem. The xylem, which is formed from procambial or cambial cells, is a heterogeneous tissue consisting of both non-conducting cells (parenchyma or woody rays and fibers) and conducting cells (vessels); because they are essential to the transportation and storage of water and minerals (crude sap). This is one of the fundamental characters of the degree of drought resistance of $P$. atlantica. As the xylem, the phloem is not homogeneous; it consists of parenchyma, fibers and conducting elements (sieve tubes), providing the transport of the organic or developed sap to the different parts of the plant.

The medullary rays (parenchymal cells) ensure and provide storage and radial 
transport of water and assimilate between the xylem and phloem [22] [27]. For the young stems have primary medullary rays (Figure 4 and Figure 5) which, according to Berthet (2006) [22], originate from pith and remain in contact with it.

As for fiber, their main function is to provide structural support for the plant [27]. They consist mainly of cellulose, with varying proportions of hemicellulose, pectin and lignin [22]. In addition to the xylem and phloem fibers, other fibrous cells, provided with a thickened wall and more or less lignified, form a discontinuous sheath around the conducting tissues. We describe here the pericyclicfibers which are dead cells, sclerenchymatous, elongated along the axis of the organ, fusiform, in kidney-shaped clusters, and up to a thickness which can vary from 30 to 50 microns, about 2\% (Table 1) (Figure 4(a) and Figure 6(d)). During its development, the fiber synthesizes the enzymes responsible for the production of lignin, which confers rigidity to its walls [28]. These fibers are resistant to compressive forces associated with the mass body subject to gravity, while permitting flexing movements under the effect of wind. This tissue contributes to the mechanical stability of the plant [25]. It ensures support for the aerial organs which have completed their growth; while the collenchyma, also participating to that support, is forming in young growing bodies (Figure 6(b)).

The collenchyma cells can be considered as parenchymal cells, specialized in supporting young tissues [27]. The collenchyma, specific to aerial organs, consists of more or less elongated living cells without lacunar spaces; with primary wall with irregular pecto-cellulosic thickening and especially unlignified. The thickness of the cellulose walls gives collenchyma cells a greater resistance to bending and tensile forces and gives the tissue its supporting character [27].

Raven et al. (2003) [28] has confirmed that as opposed to sclerenchymatous cells, collenchyma cells synthesize the enzymes responsible for the production of pectin that are responsible for the plasticity of their walls. Our findings confirm that this is an angular collenchyma characterized by thickening localized to the cell corners. This collenchyma is formed between tissues coating and the pericyclic fibers of branches and is also located along the main nervure and the leaf margin. The current results show an important development of collenchyma at the branches with a thickness varying from 40 to $180 \mu \mathrm{m}$ and from 90 to $440 \mu \mathrm{m}$ at the leaves main nervure (Table 1 and Table 2); which reflect their more or less young state. However, in older samples (Figure 4(a)) we have noticed the appearance of cork on the periphery with a few layers of parenchymal cells (cortical parenchyma) which separate pericyclic fibers from collenchyma. This latter disappears with the onset of suber and cortical parenchyma. As reported by Demalsy and Feller-Demalsy (1990) [29] the collenchyma is fleeting in trees and shrubs.

The two supporting tissues (collenchyma and sclerotic fibers) form with the parenchyma, composed of banal appearance of roughly isodiametric cells, all fundamental tissues. Parenchymal cells provide the major part of plant metabolism; they synthesize and store various organic substances [26]; they take place, 
according to the organs, in photosynthesis, reserve accumulation, the accumulation of water or specific biosynthesis [22].

At the center of the branches, is the pith, which consists of a storage parenchyma often rich in starch grain. We note that the pith is made up of cells with more or less lignified walls, perforated punctuations or plasmodesmata that allow intercellular communication and a circulation of substances within the cells (Figure 4(c) and Figure 5(d)).

Pith is also characterized by its more or less great development; it reaches a diameter of 610 microns, or $38 \%$ on average (Table 1 ). At the stems level, it often disappears with age, leaving only a small section duct.

Table 1 and Table 2 have the average thickness of the leaf epidermis which stays slightly higher than that of the branches with a percentage up to $3 \%$ of the cross section. This is explained by the presence of a film made of cutin (cuticle) covering the outer face of the epidermal cells. External cell walls of the epidermis are often thickened and impregnated with lipophilic substances (cutin, wax) [23].

The chemical composition of the walls and vacuolar content is variable and is related to the role of protection from environmental strains (radiation, drought and grazing) [27]. The cuticle generally protects the plant from drying and microorganisms infection [22]. The epidermis comprises other types of more specialized cells called protective trichomes. They maintain some freshness at the leaf area and reduce evaporation. The trichomes are distributed on the adaxial side of leaves along the midrib and margin and on the epidermis of young branches. The current measurements give the length of these trichomes hardly exceeds $30 \mu \mathrm{m}$.

Observation under a scanning electron microscope revealed more precision on the leaves of $P$. atlantica, they indicate the presence of two types of trichomes: 1) non-glandular covers (ciliated short hairs at the margin and long hair at the main nervure) and 2) Glandular secretory hairs at the abaxial surface.

Metcalfe and Chalk (1950) [30] reported that among Anacardiaceae family species glandular trichomes are responsible for the secretion of the resin. Taxonomically, the trichomes are important in terms of the genera and species classification. The anatomical difference can be used as a taxonomic key to distinguish among Pistacia species [5]. Monjauze (1980) [31] reported that some Algerian Atlas pistachio was not ciliated in the margins, and Lin et al. studies (1984) [32] also indicated that the $P$. atlantica leaves are hairless. Komarov (1949) [33] indicated that the leaves main vein is covered with hair, while the limits are rarely ciliated.

The leaves conducting system is connected to the xylem and phloem of the stem [26]. The conducting tissues consist of elongated cells in the direction of the organ (vertical system with conducting elements and vertical parenchyma and fibers) which intersects with the elongated cells in the radial direction (horizontal system made of parenchyma in rays) [25]. Conducting bundles of leaves are surrounded by a thick layer of parenchyma, the perivascular sheath, often 
associated with a significant amount of collenchyma (in the larger veins) (Figure 7 and Figure 8). The perivascular sheath is an intermediary for the transport of mesophyll compounds to ducting bundles [23].

The fundamental leaf tissues take place between the upper epidermis and lower epidermis, in an area called mesophyll (from Greek mesos, "middle" and phullon, "leaf"). The mesophyll is composed mainly of parenchyma cells containing chloroplasts that carry out photosynthesis [26].

Our observations show that the mesophyll Pistacia atlantica is characterized by a homogeneous structure fully palissadic (Figure 8(a)). This assimilation parenchyma has four cell layers which the two adaxial palisades are the longest. In total, it reaches a maximum value of 170 microns or $80 \%$ of the mesophyll thickness (Table 2).

Al-Saghir et al. (2006) [5] has reported that genus Pistacia is xerophytic and characterized by the presence of different types of adaptation to drought, as the great development of the palisadic parenchyma and the extensive root system. Moreover, forming of a characteristic layered palisadic tissue remains among the changes that accompany the dryness of the air and/or the increasing lack of water.

According to Vidal and Pognonec work (1984) [34], such a water deficit may also contribute to reduce the intercellular spaces; which explains well the absence of lacunar or spongy parenchyma in the sampled leaves. On the other hand, we note that this parenchyma exists but is less differentiated and denser to the point where he does not appear. It can also even mingle with the palisadic parenchyma due to the great development of that tissue and the resemblances between them, as Al-Saghir et al. (2006) [5] indicated also. This is a positive phenomenon for adaptation to drought: a reduction in intercellular spaces (densification of lacunar parenchyma) can participate in the limitation of water loss [35] [36].

In addition to water deficit intensity of the illumination and the position of the leaves relative to solar radiation also reflect the degree of development of the palisadic parenchyma. In the parenchyma, under the effect of intense illumination, there is the reduction of meatuses, the accumulation of starch, differentiation of palisadic tissue whose cells become elongated and the layers more numerous [36].

The importance of palisadic tissue, that is to say the number of cell layers that constitute it, can vary from one leaf to another in the same subject, depending on the illumination received by the leaves. Deysson (1965) [36] has noted that dry environments and intense illumination act the same way on the anatomical structure. According to Oppenheimer (1961) [35] the palisadic tissue that grows in dry environment consists of narrow and elongated cells; it is probably due to an adaptation to the light intensity rather than to drought. However, these anatomic variations (acclimation) exist within a subject and between subjects, depending on their exposure to light [25].

Cornic (2007) [37] has reported that the leaves, which are oriented vertically 
to the ground, often have a homogeneous structure, and one meets them in upland plants and/or very sunny locations while the leaves in horizontal position rather found in the shade. Other differentiations, of anatomical order, are observed under the effect of intense illumination, as many of the secretory elements [37].

There are cells or group of cells scattered in other tissues and which have the property to produce or secrete substances such as resin in $P$. atlantica. The resin can contribute to prevent water vapor to escape from leaves [35]. This indicates the importance of the excretory elements in this species and is drought-related factor as well.

\section{Conclusions}

The results of this study reveal that epidermis of leaves is thick and cutinized; trichomes were present in leaves, development of the palisadic parenchyma (as a result of continued solar radiation and water deficit), reduction and densification of the lacunar parenchyma; the resin was secreted and the vascular system is well developed.

In conclusion, Pistacia atlantica has xeromorphic anatomical characters, giving it a great ecological plasticity in an environmentally stressful medium. The climatic conditions of the Algerian northwester most from the ancient period to date are still favorable for better rehabilitation and maintaining of $P$. atlantica.

Possible climate changes in the global change phenomenon should not result in rarefactions or significant disappearances of Mediterranean phanerophytes. The most threatened species are much more in the near future as a result of human impacts than under climate variations [38].

\section{Acknowledgements}

The authors are grateful for Dr. Meriem Kaid-Harche, Director of Laboratory Productions, Plant and Microbial Valuations LP2VM (University of Sciences and Technology, Oran, Algeria) for providing his lab space and equipments to do this work. The authors would like to thank all the lab staff for their help and support in particular Dr. Kheira Errouane who has helped with the histological sections of this species.

\section{References}

[1] AL-Saghir, M. and Porter, D. (2012) Taxonomic Revision of the Genus Pistacia L. (Anacardiaceae). American Journal of Plant Sciences, 3, 12-32. https://doi.org/10.4236/ajps.2012.31002

[2] Quézel, P. (2000) Réflexionsur l'évolution de la flore et de la végétation au Maghreb méditerranéen. Ibis Press, Paris.

http://www.cairn.info/revue-annales-de-geographie-2006-5-page-618.htm

[3] Quézel, P. and Médail, F. (2003) Écologie et biogéographie des forêts du bassin méditerranéen. Elsevier, Paris. http://www.lavoisier.fr/livre/environnement/ecologie-et-biogeographie-des-forets-d u-bassin-mediterraneen/quezel/descriptif-9782842994518 
[4] Benhassaini, H. and Belkhodja, M. (2004) Le pistachier de l'Atlas en Algérie: Entre survie et disparition. La feuille et l'aiguille, 54, 1-2. http://www.sciencedirect.com/science/article/pii/S1876610215013612

[5] AL-Saghir, M.G., Porter, D.M. and Nilsen E.T (2006) Leaf Anatomy of Pistacia Species (Anacardiaceae). Journal of Biological Sciences, 6, 242.

https://doi.org/10.3923/jbs.2006.242.244

[6] Benhassaini, H., Mehdadi, Z., Hamel, L. and Belkhodja, M. (2007) Phytoécologie de Pistacia atlantica Desf. subsp. Atlantic adans le Nord-ouestalgérien. Cahiers Sécheresse, 18, 199-205.

[7] Belhadj, S., Derridj, A., Auda, Y., Gers, Ch. and Gauquelin, T. (2008) Analyse de la variabilité morphologique chez huit populations spontanées de Pistacia atlantica en Algérie. Botany, 86, 520-532. https://doi.org/10.1139/B08-008

[8] Amara, M. (2008) Contribution à l'étude de Pistacia atlantica Desf. dans le NordOuest Algérien: Aspects écologiques et cartographie. Mémoire de Magister, Université de Tlemcen.

[9] Amara, M. (2014) Contribution à l'étude des groupements à Pistacia atlantica subsp. atlantica dans le Nord-Ouestalgérien. These de Doctorat, Université de Tlemcen.

[10] Grundwag, M. and Werker, E. (1976) Comparative Wood Anatomy as an aid to identification of Pistacia L. Species. Israel Journal of Botany, 25, 152-167.

[11] Dong, Z. and Bass, P. (1993) Wood Anatomy of Trees and Shrubs from China. V. Anacardiaceae. International Association of Wood Anatomists Journal, 14, 87-102.

[12] El-Oqlah, A. (1996) Biosystematics Research on the Genus Pistacia in Jordan. Taxonomy, Distribution, Conservation and Uses of Pistacia Genetic Resources, Palermo, 29-30 June 1995, 12-19.

[13] AL-Saghir, M.G. and Porter, D.M. (2005) Stomatal Distribution in Pistacia sp. (Anacardiaceae). International Journal of Botany, 1,183-187. https://doi.org/10.3923/ijb.2005.183.187

[14] Belhadj, S., Derridj, A., Aigouy, T., Gers, C., Gauquelin, T. and Mevy, J.-P. (2007) Comparative Morphology of Leaf Epidermis in Eight Populations of Atlas Pistachio (Pistacia Atlantica Desf., Anacardiaceae). Microscopy Research and Technique, 70, 837-846. https://doi.org/10.1002/jemt.20483

[15] Aimé, S. and Remoaoun, K. (1988) Variabilité climatique et steppisation dans le bassin de la tafna (Oranie occidentale). Méditerranée, 63,43-51. https://doi.org/10.3406/medit.1988.2528

[16] Bagnouls, F. and Gaussen, H. (1957) Les climats biologiques et leurs classifications. Annales de Géographie, 66,193-220. https://doi.org/10.3406/geo.1957.18273

[17] Le Houérou, H.N. (1989) Classification écoclimatique des zones aride (S.I.) de l'Afrique du Nord. Ecologia Mediterranea, 15, 95-144.

[18] Le Houérou, H.N. (1995) Bioclimatologie et biogéographie des steppes arides du Nord de l'Afrique. Options méditerranéennes, C.I.H.E.A.M., Montpellier.

[19] Bouazza, M. (1995) Étude phytoécologique des steppes à Stipa tenacissima L. et à Lygeum spartum L. au Sud de Sebdou (Oranie, Algérie). Thèse doctorat EsSciences, Université de Tlemcen, Tlemcen.

[20] Alcaraz, C. (1982) La végétation de l'ouest Algérien. Thèse doctorat ès-sciences, Université de Perpignan, Perpignan.

[21] Langeron, M. (1934) Précis de microscopie. Masson et Cie, Paris. https://www.abebooks.fr/rechercher-livre/titre/precis-de-microscopie/auteur/langer on/ 
[22] Berthet, J. (2006) Dictionnaire de Biologie. De Boeck, Bruxelles. http://www.deboecksuperieur.com/ouvrage/9782804127985-dictionnaire-de-biologie

[23] Lüttge, U., Kluge, M. and Bauer, G. (2002) Botanique. Tec. \& Doc., Paris.

[24] Gorenflot, R. and Foucault, B.D. (2005) Biologie végétale: Les cormophytescours et questions de révisions. 7eme édition, Dunod, Paris.

[25] Meyer, S., Reeb, C. and Bosdeveix, R. (2004) Botanique: Biologie et physiologie végétales. Maloine, Paris.

http://www.maloine.fr/botanique-biologie-et-physiologie-vegetales-2e-ed.html

[26] Campbell, N.A., Reece, J.B. and Mathieu, R. (2006) Biologie. De Boeck, Bruxelles. https://www.pearsonhighered.com/product/Reece-Campbell-Biology-10th-Edition/ 9780321775658.html

[27] Hopkins, W.G. and Evrard, C.M. (2006) Physiologie végétale. De Boeck, Bruxelles. http://www.deboecksuperieur.com/ouvrage/9782744500893-physiologie-vegetale

[28] Raven, P.H., Evert, R.F., Eichhorn, S.E. and Bouharmont, J. (2003) Biologie végétale. De Boeck, Bruxelles. https://www.amazon.fr/Biologie-végétale-Peter-Raven/dp/2804150208

[29] Demalsy, P. and Feller-Demalsy, M.J. (1990) Seed Plants: Structure, Biology, Development. Armand Colin, Quebec, 335.

[30] Metcalfe, C.R. and Chalk, L. (1950) Anatomy of the dicotyledons: Leaves, Stem, and Wood, in Relation to taxonomy with Notes on Economic Uses. 2nd Edition, Clarendon Press, Oxford.

http://www.worldcat.org/title/anatomy-of-the-dicotyledons-leaves-stem-and-woodin-relation-to-taxonomy-with-notes-on-economic-uses/oclc/517842

[31] Monjauze, A. (1980) Connaissance du betoum Pistacia atlantica Desf. Biologie et foret. Revue Forestière Française, 4, 357-363.

[32] Lin, T.S., Crane, J.C., Ryugo, K., Polito, V.S. and Dejong, T.M. (1984) Comparative Study of Leaf Morphology, Photosynthesis, and Leaf Conductance in Selected Pistacia Species. Journal of the American Society for Horticultural Science, 109, 325-330. http://cat.inist.fr/?aModele $=$ afficheN\&cpsidt $=9649000$

[33] Komarov, V.L. (1949) Pistacia L. Flora SSSR, 14, 519-526.

[34] Vidal, A. and Pognonec, J.-C. (1984) Effet de l'alimentation en eau sur quelques caractères morphologiques et anatomiques des feuilles de soja (Glycine max (L.) Merrill). Agronomie, 4, 967-975. https://hal.archives-ouvertes.fr/hal-00884600 https://doi.org/10.1051/agro:19841007

[35] Oppenheimer, H.R. (1961) L'adaptation à la sécheresse: Le xéromorphisme. In: UNESCO, Échanges Hydriques des plantes en milieu aride ou semi-aride, Compte Rendu de recherches, UNESCO, Paris, 115-153. http://sfbv.snv.jussieu.fr/CR 2016/Hennion_CR Congres 2016.pdf

[36] Deysson, G. (1965) Éléments D’anatomie des plantes vasculaires. Société d'Édition d'Enseignement Supérieur, Paris.

[37] Cornic, G. (2007) Effets de la lumière sur la photosynthèse et sur l'appareil photosynthétique. Adaptation à l'éclairement de croissance. Photoinhibition. http://www.ese.u-psud.fr/IMG/pdf/Effets de la lumiere.pdf

[38] Quézel, P. and Médail, F. (2002) Réponses de l'élément végétal (flore et végétation du bassin méditerranéen) à d'éventuelles modifications climatiques. Changement climatique, fantasme ou réalité? Actes des tables rondes, Montpellier, 15 mai 2001, 39-45. 
Submit or recommend next manuscript to SCIRP and we will provide best service for you:

Accepting pre-submission inquiries through Email, Facebook, LinkedIn, Twitter, etc. A wide selection of journals (inclusive of 9 subjects, more than 200 journals)

Providing 24-hour high-quality service

User-friendly online submission system

Fair and swift peer-review system

Efficient typesetting and proofreading procedure

Display of the result of downloads and visits, as well as the number of cited articles Maximum dissemination of your research work

Submit your manuscript at: http://papersubmission.scirp.org/

Or contact ajps@scirp.org 